\title{
Activism and scientific research: 20 years of community action by the Vancouver area network of drug users
}

\author{
Ehsan Jozaghi ${ }^{1,2^{*}} \mathbb{D}$, Alissa M. Greer ${ }^{1,2}$, Hugh Lampkin $^{3}$ and Jane A. Buxton ${ }^{1,2}$
}

\begin{abstract}
Background: Over the past several decades, there have been numerous peer-reviewed articles written about people who use drugs (PWUDs) from the Downtown Eastside neighborhood of Vancouver, Canada. While individual researchers have engaged and acknowledged this population as participants and community partners in their work, there has been comparatively little attention given to the role of PWUDs and drug user organizations in directing, influencing, and shaping research agendas.

Methods: In this community-driven research, we examine 20 years of peer-reviewed studies, university theses, books, and reports that have been directed, influenced, and shaped by members of the activist organization the Vancouver Area Network of Drug Users (VANDU). In this paper, we have summarized VANDU's work based on different themes from each article.
\end{abstract}

Results: After applying the inclusion criteria to over 400 articles, 59 items containing peer-reviewed studies, books, and reports were included and three themes of topics researched or discussed were identified. Theme 1: 'health needs' of marginalized groups was found in 39\% of articles, Theme 2: 'evaluation of projects' related to harm reduction in 19\%, and Theme 3: 'activism' related work in 42\%. Ninety-four percent of co-authors were from British Columbia and $44 \%$ of research was qualitative. Works that have been co-authored by VANDU's members or acknowledged their participations created 628 citations. Moreover, their work has been accessed more than 149,600 times.

Conclusions: Peer-based, democratic harm reduction organizations are important partners in facilitating groundbreaking health and social research, and through research can advocate for the improved health and wellbeing of PWUDs and other marginalized groups in their community. This article also recommends that PWUDs should be more respectfully engaged and given appropriate credit for their contributions.

\section{Background}

More than 20 years ago, the city of Vancouver, Canada, was experiencing severe overdose and blood-borne disease epidemics concentrated in the Downtown Eastside (DTES) neighbourhood [1,2]. These epidemics were attributed to the ineffective and inefficient health and social policies tailored toward the people who use drugs (PWUDs) [3, 4]. The Vancouver Area Network of Drug Users (VANDU) was formed to address the gross injustice of health and

\footnotetext{
*Correspondence: ehsan.jozaghi@ubc.ca

${ }^{1}$ The British Columbia Centre for Disease Control, 655 W 12th Ave, Vancouver, BC V5Z 4R4, Canada

${ }^{2}$ The School of Population and Public Health, Faculty of Medicine, University of British Columbia, 2206 East Mall, Vancouver, BC V6T 1Z3, Canada Full list of author information is available at the end of the article
}

human rights toward PWUDs [5]. Once considered a fringe organization by many, the membership of VANDU has grown substantially and VANDU is now fully funded through the local health authority, Vancouver Coastal Health [6]. For the range of work they have done in averting blood borne infections, overdose death prevention, and other pioneering harm reduction projects, VANDU has been the recipient of a number of awards by various non-government and government organizations $[7,8]$.

Since its formation, VANDU has played a critical role in research by virtue of its familiarity with the issues that affect the health of PWUDs and the organization's ability to facilitate connections between researchers and PWUD. Many of VANDU's members reside in the DTES and are affected by poverty, social marginalization, homelessness, 
substance use disorders, mental health issues, and structural violence [9-14]. Over the past few decades, there have been numerous peer-reviewed studies and reports conducted on the marginalized and at risk population in the DTES. However, scant attention has been given to the collective role of PWUDs and the power of advocacy by marginalized members of society in influencing their health and well-being.

In 2017, a VANDU board member approached the first author for assistance to describe studies with which VANDU members and the organization had been involved in to feature the publications on VANDU's website for their twentieth anniversary. Therefore, we identified peer-reviewed studies, university theses, books, book chapters, and reports that have been directed, influenced, and shaped by VANDU members. This research characterizes these articles by theme, methodology, and social media impact in the scientific and greater community.

\section{Methods}

The primary objective and scope of this study was to compile and summarize a review of the research and policy projects that VANDU has been involved and acknowledged in. The key indicators of interest were authorship, publication type, method, impact, and subject matter, or 'theme', of the publication. In order to identify relevant publications and information, we searched Google Scholar since it is known to capture not only all peer-reviewed studies that Medline, Web of Science, Scopus or Pubmed often miss, but also theses, reports, and other gray literature. In addition, Google Scholar better captures the citation impact of articles since Medline, Pubmed, Web of Science, and Scopus are not focused on reports, theses, books, and book chapters. For this article, we focus on projects and papers that VANDU had been involved in and published up until February 26, 2018.

The Google Scholar search column, "Vancouver Area Network of Drug Users" was searched with no restrictions on the publication year from the first page of search engine results to the last page because the search engine "reports with no details of the means by which ... [the results] are ordered" [15]. Publications were included if they either identified "Vancouver Area Network of Drug Users" or a VANDU member as a co-author, or thanked the membership for their direct contribution to the project. As well, publications were only included if they were written in the English language.

The studies that met the initial assessment of VANDU authorship or direct involvement were reviewed in full. Study content was summarized, and methodology, impact, author's affiliation, and role (researcher, doctoral student or VANDU/community partner) at the time of the research were identified. The geographic regions in which the co-authors were based at the time of the research/publication were also identified.
Extracted data was compiled into tables and the study content was explored to identify topic themes. The themes were derived by reviewing each study and identifying commonalities between articles and their overall objectives. The themes identified are mutually exclusive because each theme is unique, representing work that VANDU as an author organization or a supporting partner has been able to achieve through their research activities.

Study methodology was categorized as qualitative, quantitative, or other. Several measures of media impact were generated from the journals, universities, and sites that report downloads and social media impacts such as Altmetric scores (for BMC, Taylor \& Francis, Wiley, Springer and SAGE journals) and PlumX metrics (for Elsevier journals). Altmetric and PlumX metrics are used to measure the broader research impacts in social web via different non-academic sources, such as news articles citing the study, blogs, Wikipedia, video uploads, Twitter posts, Mendeley users, Google+ posts, Reddit, and Facebook shares [16-18]. Citation counts of the studies were captured via Google Scholar. The information related to articles (e.g., research, opinion, and letter), and thesis downloads/views was accessed from the journal or university websites.

A printed summary of identified articles were presented to the VANDU board in August, 2017; the board decided to pursue an academic publication, discussed the concept for this manuscript, and identified HL as VANDU's appointed author. A printed draft manuscript was presented to VANDU for input in November, 2017; subsequently VANDU members, including author HL, presented preliminary results at three local conferences and lecture series. Members of the board were supported in these knowledge translation activities by receiving poster printing costs, transportation, registration fees and honoraria. EJ facilitated discussions with VANDU board members as they reviewed printed updated manuscript drafts to provide further feedback which was incorporated prior to article submission and in the response to reviewers. In January 2018, VANDU's appointed author (HL) and the board members were provided with an updated printed summary of the identified articles. In addition, an updated printed draft of the manuscript and tables were given to VANDU board members for further feedback in March 2018.

\section{Results}

The literature search identified more than 400 articles. A total of 341 articles were excluded because they were determined from the review of title, abstract and body not to be relevant. A total of 59 articles containing peer-reviewed studies, books, book chapters, theses, and reports were identified. Three themes of topics researched or discussed in the articles were identified. Theme 1, 'health needs', was based on the health and wellbeing of marginalized groups 
(e.g. sex workers, PWUD, illicit drinkers, and DTES residents). Theme 2, 'evaluation of projects', described and evaluated harm reduction projects (e.g., unsanctioned needle distribution, injection rooms, smoking rooms, injection support teams and harm reduction training/education). Finally, Theme 3, 'activism', contained studies that investigated or described the impacts of drug user activism and organizing in the DTES community and beyond. The articles are categorized by author, year of publication, title, type of publication, methodology, and theme in Table 1. Moreover, for research items associated with an academic journal, the impact factor is reported.

As shown on Tables 1, 39\% ( $n=23)$ of publications were categorized into Theme 1 (health needs), $19 \%(n=11)$ into Theme 2 (evaluation of projects), and $42 \%(n=25)$ into Theme 3 (activism). Peer-reviewed research articles represented $56 \%$ of the publications $(n=33)$, books or book chapters comprised of $7 \%(n=4)$, theses $15 \%(n=9)$, and other publications (e.g., Health News, Letters to the editor, Reports, and Opinions) comprised of $22 \%(n=13)$. The methodology of the studies, citations, social media impact, and downloads are shown in Table 2 based on their thematic categorizations. Table 2 shows the largest proportion of the articles (44\%) were qualitative. Theme 1 had the highest qualitative and quantitative categories, while Theme 3 had the highest 'other' methodology. Theme 2 had the lowest number of articles but the highest citations and Altmetric scores. Finally, Themes 2 and 3 had the most accessed articles both greater than 64,000.

Table 3 displays the role and geographic regions of the co-authors. The vast majority of co-authors are from British Columbia where VANDU is located.

The majority of stakeholders that engaged with VANDU were researchers from local universities and institutes. However, only four studies named community researchers from VANDU or PWUDs as first author. The senior, junior, and other researchers outlined in Table 3 represent a group of authors who, at the time of the publication, held tenure track or other scientific positions affiliated with a university or a lab. VANDU and the community partners are authors who are affiliated with VANDU or other organizations that work under the umbrella of VANDU. Finally, the last category on Table 3, labeled as student/postdoctoral are authors who at the time of publication were identified as students or postdoctoral fellows. The information regarding academic ranking is important because it not only emphasizes the reciprocal knowledge transfer between PWUDs as experts, but it also shows the training of many researchers at the time of publication in the community.

\section{Discussion}

VANDU is one of the first and longest running drug user organizations in North America that has advocated for the health and wellbeing of PWUDs and marginalized members in one of the poorest urban postal codes in Canada. While previous research have shown the effectiveness of programs that are informed, run, or organized by PWUD [19-24], drug user organizations like VANDU seldom been evaluated for their role in research and policy [25]. However, as our review has shown, there is enormous potential for PWUDs and other community researchers to promote advocacy, equity, harm reduction, and inclusion by engaging with similar organizations.

This research has demonstrated that over the past two decades VANDU has facilitated numerous published studies relating to the health of their members and the people from their community. The three themes identified 'health needs', 'evaluation of projects', and 'advocacy' - are important because they display the scientific output of PWUDs and their community.. The second theme, demonstrates that VANDU members have been at the forefront of harm reduction innovation and mobilization by evaluating and describing their groundbreaking harm reduction programs, such as unsanctioned user-run injection and smoking rooms. Finally, articles that discussed the impact of collective activism and organizing of PWUD indicate the capacity and enormous potential of peers as individuals and groups in health and harm reduction initiatives.

Although not fully evaluated in this research, a closer look at the journal impact factors of the publications that VANDU or its members have been named as co-authors shows the quality and breadth of work that PWUDs have been involved in [26]. For instance, many publications have been featured in top ranking substance use journals such as Addiction, Journal of Urban Health, The International Journal of Drug Policy, Harm Reduction Journal, The Canadian Medical Association Journal, AIDS and Behavior, The Canadian Journal of Public Health, and Social Science $\&$ Medicine to name a few. Moreover, the noted publications showcase the breadth of expertise of VANDU membership, and their innovation to tackle serious public health issues because many of their harm reduction programs, such as unsanctioned peer-run injection room, were mobilized through an organic, member driven processes. The noted unsanctioned user-run injection room was later evaluated through external reviewers via qualitative [27] and cost-effectiveness evaluations [28]. Therefore, VANDU as a user-run advocacy group has shown its enormous depth and innovation, as shown in the research above by implementing interventions that not only improve health and wellbeing of its members, but also through its economic impact by reducing health care costs from overdose and other illness prevented through these programs.

However, we noted that VANDU and its membership have been involved in many projects that did not meet the inclusion criteria of our review - that is, publications did not acknowledge or include them as co-authors. The issue of authorship highlights several barriers that relate 
Table 1 The summary of peer-reviewed studies, reports, theses, books, \& book chapters involving VANDU members

\begin{tabular}{|c|c|c|c|c|c|}
\hline Authors & Year & Publication & Type & Method & Theme \\
\hline Osborn, Boyd \& Columbia [44] & 1998 & Environment and Planning: Society and Space $(2.031)^{* \boldsymbol{\top}}$ & Research & Other & 3 \\
\hline Osborn [45] & 1999 & Arsenal Pulp Press ${ }^{\ddagger}$ & Book & Other & 3 \\
\hline Kerr et al. [46] & 2001 & Health Canada & Report & Qualitative & 3 \\
\hline Rossi \& Pacey [47] & 2002 & Canadian HIV/AIDS Policy \& Law Review & Health News & Other & 2 \\
\hline Wood et al. [48] & 2003 & Journal of Urban Health (1.959) & Research & Quantitative & 2 \\
\hline Kerr et al. [49] & 2003 & Journal of Drug Issues (1.161) & Research & Quantitative & 3 \\
\hline Silversides [50] & 2004 & Canadian Medical Association Journal (6.784) & Research & Other & 3 \\
\hline Alleyne et al. [51] & 2004 & Health Canada and the Canadian Centre on Substance Abuse & Report & Other & 3 \\
\hline Jürgens [52] & 2005 & International HIV/AIDS Alliance \& Canadian HIV/AIDS Legal Network & Report & Other & 3 \\
\hline Kerr et al. [53] & 2005 & Journal of Urban Health (1.959) & Research & Quantitative & 2 \\
\hline Kerr et al. [8] & 2006 & International Journal of Drug Policy (3.479) & Research & Qualitative & 3 \\
\hline Shannon et al. [54] & 2006 & Harm Reduction Journal (1.880) & Research & Quantitative & 1 \\
\hline Osborn \& Small [55] & 2006 & International Journal of Drug Policy (3.479) & Research & Other & 1 \\
\hline De Sousa [56] & 2006 & University of British Columbia: PhD Dissertation & Thesis & Qualitative & 1 \\
\hline Banga [57] & 2007 & University of British Columbia: PhD Dissertation & Thesis & Qualitative & 1 \\
\hline Shannon et al. [58] & 2008 & Substance use \& Misuse (1.234) & Research & Quantitative & 1 \\
\hline Howard [59] & 2008 & Simon Fraser University: PhD Dissertation & Thesis & Qualitative & 3 \\
\hline Salmon et al. [60] & 2009 & Women's Health Research Institute & Report & Qualitative & 1 \\
\hline Boyd, MacPherson \& Osborn [61] & 2009 & Fernwood Publication & Book & Other & 3 \\
\hline Campbell, Boyd \& Culbert [62] & 2009 & Greystone Books & Book & Other & 3 \\
\hline Wilson [63] & 2009 & Simon Fraser University: PhD Dissertation & Thesis & Qualitative & 3 \\
\hline Rachlis et al. [64] & 2010 & Substance use \& Misuse (1.234) & Research & Quantitative & 1 \\
\hline Hayashi et al. [25] & 2010 & International Journal of Drug Policy (3.479) & Research & Quantitative & 2 \\
\hline $\begin{array}{l}\text { Vancouver Area Network of } \\
\text { Drug Users [65] }\end{array}$ & 2010 & City of Vancouver & Research & Quantitative & 1 \\
\hline Lloyd-Smith [66] & 2010 & Harm Reduction Journal (1.880) & Research & Quantitative & 1 \\
\hline Kruk \& Banga [67] & 2011 & Canadian Journal of Community Mental Health ${ }^{a}$ & Research & Qualitative & 1 \\
\hline Kendall [68] & 2011 & Government of British Columbia & Report & Qualitative & 1 \\
\hline Reid [69] & 2011 & Simon Fraser University: Master of Public Policy & Thesis & Qualitative & 1 \\
\hline Crabtree et al. [70] & 2011 & UBC Medical Journal ${ }^{a}$ & Research & Qualitative & 1 \\
\hline Small et al. [71] & 2012 & Substance use \& Misuse (1.234) & Research & Qualitative & 2 \\
\hline McNeil [72] & 2013 & University of British Columbia: PhD Dissertation & Thesis & Qualitative & 1 \\
\hline Grant et al. [73] & 2013 & UBC Medical Journal ${ }^{a}$ & Research & Qualitative & 1 \\
\hline $\begin{array}{l}\text { Boyd \& NAOMI Patients } \\
\text { Association [33] }\end{array}$ & 2013 & Harm Reduction Journal (1.880) & Research & Qualitative & 3 \\
\hline Callon et al. [74] & 2013 & Harm Reduction Journal (1.880) & Research & Qualitative & 2 \\
\hline Ormond [75] & 2013 & Radical Criminology ${ }^{a}$ & Opinion & Other & 1 \\
\hline McNeil et al. [27] & 2014 & AIDS and Behavior (2.916) & Research & Qualitative & 2 \\
\hline McNeil et al. [76] & 2014 & International Journal of Drug Policy (3.479) & Research & Qualitative & 1 \\
\hline $\begin{array}{l}\text { Jozaghi \& Vancouver Area } \\
\text { Network of Drug Users [6] }\end{array}$ & 2014 & Harm Reduction Journal (1.880) & Research & Other & 2 \\
\hline McNeil et al. [77] & 2015 & International Journal of Drug Policy (3.479) & Research & Qualitative & 2 \\
\hline Jozaghi \& Vancouver Area & 2015 & Health \& Justice $^{a}$ & Research & Other & 2 \\
\hline
\end{tabular}


Table 1 The summary of peer-reviewed studies, reports, theses, books, \& book chapters involving VANDU members (Continued)

\begin{tabular}{|c|c|c|c|c|c|}
\hline Authors & Year & Publication & Type & Method & Theme \\
\hline Crabtree [78] & 2015 & University of British Columbia: PhD Dissertation & Thesis & Qualitative & 3 \\
\hline Jozaghi [19] & 2015 & Simon Fraser University: PhD Dissertation & Thesis & Qualitative & 3 \\
\hline Himsworth et al. [79] & 2015 & Vector-Borne and Zoonotic Diseases (2.045) & Research & Quantitative & 1 \\
\hline Westfall [80] & 2015 & Simon Fraser University: Master of Public Policy & Thesis & Qualitative & 1 \\
\hline Jozaghi, Lampkin \& Andresen [20] & 2016 & Harm Reduction Journal (1.880) & Research & Qualitative & 2 \\
\hline Crabtree et al. [81] & 2016 & Harm Reduction Journal (1.880) & Research & Qualitative & 1 \\
\hline Smith [82] & 2016 & $\begin{array}{l}\text { Intersectionalities: A Global Journal of Social Work } \\
\text { Analysis, Research, Polity, and Practice }\end{array}$ & Research & Other & 3 \\
\hline Greer et al. [83] & 2016 & British Columbia Centre for Disease Control & Report & Other & 3 \\
\hline Goodman et al. [84] & 2017 & Social Science \& Medicine (2.797) & Research & Qualitative & 1 \\
\hline $\begin{array}{l}\text { Boyd, Murray, SNAP \& } \\
\text { MacPherson [34] }\end{array}$ & 2017 & Harm Reduction Journal (1.880) & Research & Qualitative & 3 \\
\hline Jozaghi \& Marsh [41] & 2017 & Canadian Journal of Public Health & Letter & Other & 3 \\
\hline Thomson et al. [85] & 2017 & Addiction & Letter & Other & 3 \\
\hline $\begin{array}{l}\text { Boyd, Murray \& NAOMl } \\
\text { Patients Association [86] }\end{array}$ & 2017 & Critical Inquiries for Social Justice in Mental Health & Book chapter & Other & 3 \\
\hline Damon et al. [36] & 2017 & Social Science \& Medicine (2.797) & Research & Other & 3 \\
\hline Greer et al. [87] & 2017 & British Columbia Centre for Disease Control & Report & Other & 3 \\
\hline Bouchard et al. [88] & 2018 & International Journal of Drug Policy (3.479) & Research & Other & 3 \\
\hline Lee et al. [89] & 2018 & Emerging Infectious Diseases (8.222) & Research & Quantitative & 1 \\
\hline Rothenburger et al. [90] & 2018 & EcoHealth (2.252) & Research & Quantitative & 1 \\
\hline Jozaghi et al. [91] & 2018 & Canadian Journal of Public Health & Letter & Other & 3 \\
\hline
\end{tabular}

*The journal impact factors of the publication are represented in the parentheses

${ }^{\top}$ The impact factor of the journal is for the year 2017 and not for the year in which the article was published

${ }^{*}$ The impact factor of the journal is not reported if it is a letter, report, theses, book or book chapter

${ }^{a}$ The noted journals have no reported impact factors

to the equity and inclusion of PWUDs. First, the International Committee of Medical Journal Editors [29] defines authorship based on four rigid criteria that would disqualify many PWUDs due to their literacy. However, contributions may be considerable in study design and execution, and interpretation of findings; therefore we recommend changes so that PWUDs' expertise can be acknowledged through involvement and validity. Second, academic researchers often hold the power to include or not include PWUDs as authors on publications. When considering the power imbalance between the researchers and the participants, these inequalities highlight that participation may not be used to empower PWUDs, but rather to reach the research agendas and advance the careers of academics outside of the community [30-32]. While authorship holds importance for academic researchers in terms of legitimacy and career advancement, it is also important for marginalized communities whose authorship represents the expertise, contributions, and legitimacy of their work. It is also important to emphasize that authorship does not necessarily mean members of the community have been meaningfully engaged. PWUDs may be added to publications to make the work appear community-engaged when in fact their insights have not been integrated and input is tokenistic.

Table 2 Summarizing the research themes in terms of methodology and the research impact

\begin{tabular}{lllllll}
\hline Research Theme & Qualitative & Quantitative & Others & Citations & Altmetric score & Accessed \\
\hline${\text { Theme } 1^{*}}^{*}$ & $12(52 \%)$ & $8(35 \%)$ & $3(13 \%)$ & 161 & 201 & 21,341 \\
Theme 2" $^{*}$ & $5(46 \%)$ & $3(27 \%)$ & $3(27 \%)$ & 248 & 353 & 64,004 \\
${\text { Theme } 3^{*}}^{\text {Total }}$ & $9(36 \%)$ & $1(4 \%)$ & $15(60 \%)$ & 217 & 268 & 64,255 \\
\hline
\end{tabular}

*Theme 1 = Health needs of marginalized groups

"Theme 2 = Evaluation of projects

"Theme $3=$ Impact of drug user activism 
Table 3 Summarizing the research themes in terms of the geographic affiliations and coauthors' roles

\begin{tabular}{lllllll}
\hline Research Theme & B.C. co-authors & $\begin{array}{l}\text { Rest of Canada } \\
\text { co-authors }\end{array}$ & $\begin{array}{l}\text { International } \\
\text { co-authors }\end{array}$ & $\begin{array}{l}\text { Senior, Junior, \& } \\
\text { other Researchers }\end{array}$ & $\begin{array}{l}\text { VANDU \& the } \\
\text { community partners }\end{array}$ & $\begin{array}{l}\text { Student/Postdoctoral } \\
\text { Theme 1 }^{*}\end{array}$ \\
Theme 2 $^{\text {q }}$ & $106(90 \%)$ & $9(7 \%)$ & $3(3 \%)$ & $50(42 \%)$ & $39(33 \%)$ & $29(25 \%)$ \\
Theme3 $^{*}$ & $41(100 \%)$ & $0(0 \%)$ & $0(0 \%)$ & $20(49 \%)$ & $12(29 \%)$ & $9(22 \%)$ \\
Total $^{28(97 \%)}$ & $2(2 \%)$ & $1(1 \%)$ & $27(30 \%)$ & $38(42 \%)$ & $26(28 \%)$ \\
\end{tabular}

*Theme 1 = Health needs of marginalized groups

"Theme 2 = Evaluation of projects

"Theme $3=$ Impact of drug user activism

${ }^{\top}$ Community partners: 1) the BC/Yukon Association of Drug War Survivors, 2) the British Columbia Association for People on Methadone, 3) the Eastside Illicit

Drinkers Group for Education, 4) the VANDU's Tuesday Education Group, 5) SALOME/NAOMI Association of Patients, and 6) the Western Aboriginal Harm

Reduction Society

Based on our findings, it is not surprising that PWUDs and others have advocated for greater and more meaningful involvement for members of the DTES. This advocacy is based on legitimizing and valuing PWUDs contributions and expertise, and also to strengthen the inclusion of this community in decisions and actions that affect their lives [33-35].

The "Nothing About Us Without Us" movement has essentially advocated for the broader goals of knowledge transfer where PWUDs have the knowledge and the background to work as researchers "beyond tokenistic involvement in research" [35] p. 6. While previous researchers have laid the foundation for hiring or engaging with PWUD $[24,35]$ we recommend that future researchers not only acknowledge the participation of PWUDs, but offer capacity building among PWUD to engage them in writing, and authorship - including other avenues of knowledge translation such as media, social media, policy work, and grant writing. We also recommend that every attempt be made to create equitable, fair, and legitimate capacity building opportunities for PWUDs, such as fair access to computers, language, education, and engagement to allow those who show interest to be included. In our own project, it was important to support VANDU by printing out the draft of our manuscript, printing posters, providing the registrations, transportations and financial support so it can be presented orally. As well, it was critical to seek input from its Board and appointed author (HL) at multiple points in time, and to follow up on the outcome of any feedback that was given. We learned that for this group, presenting and using the findings was much more important than the actual writing of the manuscript itself. Along those lines, it is important for peer-reviewed journals to remove some of the rigid requirement for marginalized populations in terms of authorship and access, to not only empower community members, but to reinforce the importance of people with lived experiences as 'experts'.

Across North America, Europe, Australia, and Asia, PWUDs and other residents of the DTES have been touted as one of the most highly researched populations in the world. In our consultation with VANDU during this process, we noted that several articles that had been published were unknown to VANDU membership. This points to a concern that the results of community-engaged studies are often not disseminated back to this community [36], or leveraged to build the capacity of the community [37].

This study has several limitations that need to be acknowledged. First, some journals did not have standardized reporting for scores related to social networks (e.g., Twitter, Facebook, Reddit, etc.) and article access or downloads. For example, the majority of journals reflected their social media outcomes via Altmetric scores while Elsevier journals reported the outcomes through PlumX metrics which made it extremely difficult to compare. In addition, while BMC, Springer, Sage and Taylor \& Francis journals report article downloads/views, this information is not accessible via Wiley and Elsevier journals. Second, the choice of indicators, such as seniority of authors, article access, or Altmetric scores will change with time. For example, many researchers with established rapport with VANDU have moved to more senior academic positions in each subsequent publication. Third, it is important to emphasize some of the shortcomings of the Google Scholar as the only source for identifying articles which may include a lack of information on what constitutes 'scholarly' articles, citation overestimations, and unreliable comprehensiveness [3840]. Fourth, all the articles reviewed show a positive outcome, which could be attributed to publication bias. Moreover, most often VANDU/community members are not versed in quantitative, qualitative and critical analysis that most journals require placing them at significant disadvantage. Also the emphasis on the independence of evaluators in a positivist tradition can obscure or devalue the contributions of community members in evaluation designs, drawing on other approaches to knowledge construction.

Finally, it is important to emphasize that some of the articles highlighted in this review, such as Boyd, \& NAOMI Patients Association [33], Demon et al. [36], and Jozaghi \& Marsh [41], represent various groups that are supported directly or indirectly through VANDU. For example, 1) the BC/Yukon Association of Drug War Survivors, 2) the British Columbia Association for People on Methadone, 3) the Eastside Illicit Drinkers Group for Education, 4) the 
VANDU's Tuesday Education Group, 5) SALOME/NAOMI Association of Patients, and 6) the Western Aboriginal Harm Reduction Society. However, involving the noted groups beyond the VANDU's board involvement would have been an audience for the work to be presented to, without the stakeholders having the opportunity to get involved in the research. In other words, without the financial support or resources to provide adequate capacity building, asking the above noted groups to contribute as an author in this research would have been counter- productive and would have set the bar for authorship very low. However, we were able to engage $\mathrm{HL}$ as the appointed member of VANDU in a meaningful process.

\section{Conclusions}

In summary, this study showcases the range of projects that VANDU has been included in to date, and highlights the capacity, expertise, and knowledge that PWUDs offer to community-engaged work. In the past two decades VANDU has been integral to some of the most pioneering harm reduction projects and research. By fully acknowledging the contributions of PWUDs, research has the power to legitimize the expertise and lived experience that PWUDs bring to various research contexts and ultimately influence policies and other decisions that affect their lives. As other jurisdictions look for ways to tackle health and harm reduction issues related to drug use, including the growing synthetic opioid epidemic [42, 43], it is our hope that activism, advocacy, and community-engaged research can inspire other initiatives to include and acknowledge PWUDs as true partners.

\section{Abbreviations}

DTES: Downtown Eastside; PWUDs: People who use drugs;

VANDU: Vancouver Area Network of Drug Users

\begin{abstract}
Acknowledgements
The authors would like to thank the VANDU board for providing time and space for the first author to present the research summaries, drafts and tables during their meetings. We also would like to thank VANDU board members, who have presented the earlier versions of this draft at various conferences, such as the British Columbia Public Health Association Conference in November 2017, and the Faculty of Medicine Research Trainee Day \& Lecture Series in February, 2018. In particular, we would like to thank the following individuals who directly or indirectly contributed to this research: Alexis Crabtree, Dave Hamm, Samona Marsh, Kevin Yake, Martin Stewart, Karen Ward, Aiyanas Ormond, Marion Allart, and Camille Drexl. The Canadian Institutes of Health Research Postdoctoral Fellowship (201511MFE358449-223266) supported Ehsan Jozaghi's work on this research. Vanier Canada Graduate Scholarship supported the work by Alissa M. Greer.
\end{abstract}

\section{Availability of data and materials}

All data generated or analyzed during this study are included in this manuscript.

\section{Authors' contributions}

EJ designed the study, developed the methodology, conducted the analysis, contributed to the writing, formatted the references, and drafted the tables AMG and JAB contributed to the methodology, results, discussion, theory, writing, tables, and references. $\mathrm{HL}$ in addition to his contributions to the tables, writing and references also contributed to the community engagement and participation of VANDU. All authors read and approved the final results and writing of the manuscript.
Ethics approval and consent to participate

Not applicable because this research used secondary data available to public via World Wide Web.

\section{Competing interests}

The methodology, design and approach in this study by authors are not influenced or directed by the British Columbia Centre for Disease Contro (BCCDC). The research approach, findings and recommendations of this study may not necessarily express the views of the BCCDC. To address the issue of lack of power for non-academic partners in a community-driven research we acknowledge the value of co-creation, internal validity and the competing interest that may inherently be produced.

\section{Publisher's Note}

Springer Nature remains neutral with regard to jurisdictional claims in published maps and institutional affiliations.

\section{Author details}

${ }^{1}$ The British Columbia Centre for Disease Control, 655 W 12th Ave, Vancouver, BC V5Z 4R4, Canada. ${ }^{2}$ The School of Population and Public Health, Faculty of Medicine, University of British Columbia, 2206 East Mall, Vancouver, BC V6T 1Z3, Canada. ${ }^{3}$ Vancouver Area Network of Drug Users, 380 E Hastings St, Vancouver, BC V6A 1P4, Canada.

Received: 7 March 2018 Accepted: 17 May 2018

Published online: 22 May 2018

\section{References}

1. Smith HA. Planning, policy and polarisation in Vancouver's downtown eastside. Tijdschr Econ Soc Ge. 2003:94(4):496-509.

2. Wood E, Tyndall MW, Spittal PM, Li K, Hogg RS, O'Shaughnessy MV, Schechter MT. Needle exchange and difficulty with needle access during an ongoing HIV epidemic. Int J Drug Policy. 2002;13(2):95-102.

3. Fischer B, Rehm J, Blitz-Miller T. Injection drug use and preventive measures: a comparison of Canadian and western European jurisdictions over time. C Med Assoc J. 2000;162(12):1709-13.

4. Tyndall MW, Craib KJ, Currie S, Li K, O'shaughnessy MV, Schechter MT. Impact of HIV infection on mortality in a cohort of injection drug users. JAIDS. 2001;28(4):351-7.

5. Jozaghi E. The role of drug users' advocacy group in changing the dynamics of life in the downtown eastside of Vancouver, Canada. J Subs Use. 2014;19(1-2):213-8.

6. Jozaghi E, Vancouver area network of drug users. A cost-benefit/costeffectiveness analysis of an unsanctioned supervised smoking facility in the downtown eastside of Vancouver, Canada. Harm Reduct J. 2014;1 1(1):30

7. Baker R. Vancouver Fire and Rescue Services honours exemplary citizens. CBC News. 2016. Retrieved, august, 3rd, 2017 from: http://www.cbc.ca/news/ canada/british-columbia/vancouver-fire-and-rescue-services-recognizescitizens-1.3802254

8. Kerr T, Small W, Peeace W, Douglas D, Pierre A, Wood E. Harm reduction by a "user-run" organization: a case study of the Vancouver area network of drug users (VANDU). Int J Drug Policy. 2006;17(2):61-9.

9. Kazempiur A, Halli SS. Neighbourhood poverty in Canadian cities. Can J Sociol. 2000;25(3):369-81.

10. Miller CL, Johnston C, Spittal PM, Li K, LaLiberté N, Montaner JS, Schechter MT. Opportunities for prevention: hepatitis $C$ prevalence and incidence in a cohort of young injection drug users. Hepatology. 2002;36(3):737-42.

11. Shannon K, Kerr T, Allinott S, Chettiar J, Shoveller J, Tyndall MW. Social and structural violence and power relations in mitigating HIV risk of drug-using women in survival sex work. Soc Sci \& Med. 2008;66(4):911-21.

12. Spittal PM, Craib KJ, Wood E, Laliberté N, Li K, Tyndall MW, O'shaughnessy MV, Schechter MT. Risk factors for elevated HIV incidence rates among female injection drug users in Vancouver. C Med Assoc J. 2002;166(7):894-9.

13. Wood E, Kerr T. What do you do when you hit rock bottom? Responding to drugs in the city of Vancouver. Int J Drug Policy. 2006;17(2):55-60.

14. Werb D, Debeck K, Kerr T, Li K, Montaner J, Wood E. Modelling crack cocaine use trends over 10 years in a Canadian setting. Drug Alcohol Rev. 2010;29(3):271-7.

15. Haddaway NR, Collins AM, Coughlin D, Kirk S. The role of Google scholar in evidence reviews and its applicability to grey literature searching. PLoS One. 2015 Sep 17;10(9):e0138237. 
16. Priem J, Groth P, Taraborelli D. The altmetrics collection. PLoS One. 2012; 7(11):e48753.

17. Mohammadi E, Thelwall M, Haustein S, Larivière $V$. Who reads research articles? An altmetrics analysis of Mendeley user categories. J Assoc Info Sci Tech. 2015;66(9):1832-46.

18. Barbaro A, Gentili D, Rebuffi C. Altmetrics as new indicators of scientific impact. J Eur Assoc Health Info Libraries. 2014;10(1):3-6.

19. Jozaghi E. The role of peer drug users' social networks and harm reduction programs in changing the dynamics of life for people who use drugs in the downtown eastside of Vancouver, Canada. 2015. Doctoral dissertation: Arts and Social Sciences.

20. Jozaghi E, Lampkin H, Andresen MA. Peer-engagement and its role in reducing the risky behavior among crack and methamphetamine smokers of the downtown eastside community of Vancouver, Canada. Harm Reduct J. 2016:13(1):1-9.

21. Broadhead RS, Heckathorn DD, Weakliem DL, Anthony DL, Madray H, Mills $\mathrm{RJ}$, Hughes J. Harnessing peer networks as an instrument for AIDS prevention: results from a peer-driven intervention. Public Health Rep. 1998; 113(Suppl 1):42-57.

22. Des Jarlais DC, Semaan S. HIV prevention for injecting drug users: the first 25 years and counting. Psychosom Med. 2008;70(5):606-11.

23. Grund JP, Blanken P, Adriaans NF, Kaplan CD, Barendregt C, Meeuwsen M. Reaching the unreached: targeting hidden IDU populations with clean needles via known user groups. J Psychoactive Drugs. 1992;24(1):41-7.

24. Greer AM, Luchenski SA, Amlani AA, Lacroix K, Burmeister C, Buxton JA. Peer engagement in harm reduction strategies and services: a critical case study and evaluation framework from British Columbia, Canada. BMC Public Health. 2016;16(1):452.

25. Hayashi K, Wood E, Wiebe L, Qi J, Kerr T. An external evaluation of a peerrun outreach-based syringe exchange in Vancouver, Canada. Int J Drug Policy. 2010;21(5):418-21.

26. Clarivate Analytics. (2017). InCites Journal Citation Reports: Journal impact factor for 2017. Philadelphia, Pennsylvania, United States.

27. McNeil R, Small W, Lampkin H, Shannon K, Kerr T. "People knew they could come here to get help": an ethnographic study of assisted injection practices at a peer-run 'unsanctioned'supervised drug consumption room in a Canadian setting. AIDS Behavior. 2014;18(3):473-85.

28. Jozaghi E, \& Vancouver Area Network of Drug Users. Exploring the role of an unsanctioned, supervised peer driven injection facility in reducing HIV and hepatitis $\mathrm{C}$ infections in people that require assistance during injection. Health Justice, 2015; 3(1), 1-10

29. International Committee of Medical Journal Editors. Defining the Role of Authors and Contributors. 2018. Accessed from: http://www.icmje.org/ recommendations/browse/roles-and-responsibilities/defining-the-role-ofauthors-and-contributors.html

30. Brizay U, Golob L, Globerman J, Gogolishvili D, Bird M, Rios-Ellis B, Rourke SB, Heidari S. Community-academic partnerships in HIV-related research: a systematic literature review of theory and practice. J Int AIDS Soc. 2015;18(1):1-12.

31. Greene S. Peer research assistantships and the ethics of reciprocity in community-based research. J Empir Res Hum Res. 2013;8(2):141-52.

32. Jagosh J, Macaulay AC, Pluye P, Salsberg J, Bush PL, Henderson J, Sirett E, Wong G, Cargo M, Herbert CP, Seifer SD. Uncovering the benefits of participatory research: implications of a realist review for health research and practice. Milbank Q. 2012;90(2):311-46.

33. Boyd $S$, \& NAOMI Patients Association. Yet they failed to do so. Recommendations based on the experiences of NAOMI research survivors and a call for action. Harm Reduct J. 2013;10(1):1-13.

34. Boyd S, Murray D. SNAP, \& MacPherson D. Telling our stories: heroin-assisted treatment and SNAP activism in the downtown eastside of Vancouver. Harm Red J. 2017;14(1):1-14

35. Closson K, McNeil R, McDougall P, Fernando S, Collins AB, Turje RB, Howard T, Parashar S. Meaningful engagement of people living with HIV who use drugs: methodology for the design of a peer research associate (PRA) hiring model. Harm Reduct J. 2016:13(1):1-7.

36. Damon W, Callon C, Wiebe L, Small W, Kerr T, McNeil R. Community-based participatory research in a heavily researched inner city neighbourhood: perspectives of people who use drugs on their experiences as peer researchers. Social Scie Medicine. 2017;176:85-92.

37. Wright MT. What is participatory Health Research? A position paper of the international collaboration for participatory health ResearchMichael T. Wright Eur J Public Health 2015; 25(suppl_3).
38. Boeker M, Vach W, Motschall E. Google scholar as replacement for systematic literature searches: good relative recall and precision are not enough. BMC Med Res Methodol. 2013;13:131.

39. De Winter JC, Zadpoor AA, Dodou D. The expansion of Google scholar versus web of science: a longitudinal study. Scientometrics. 2014;98:1547-65.

40. Gehanno JF, Rollin L, Darmoni S. Is the coverage of Google scholar enough to be used alone for systematic reviews. BMC Med Inform Decis Mak. 2013;13:7.

41. Jozaghi E, Marsh S. Missing the trends in the fentanyl overdose crisis: the need for immediate intervention in small and rural communities. Can J Public Health. 2017;108(4):457.

42. Kral AH, Davidson PJ. Addressing the Nation's opioid epidemic: lessons from an unsanctioned supervised injection site in the US. Am J Prev Med. 2017; 53(6):919-22.

43. Davidson PJ, Lopez AM, Kral AH. Using drugs in un/safe spaces: impact of perceived illegality on an underground supervised injecting facility in the United States. Int J Drug Policy. 2018;53:37-44.

44. Osborn B, Boyd S, Columbia B. Raise shit. Enviro Plan D: Soci Space. 1998;16: 280-8.

45. Osborn B. Hundred block rock: Arsenal pulp press; 1999.

46. Kerr T, Douglas D, Peeace W, Pierre A, Wood E. Responding to an Emergency: Education, Advocacy and Community Care by a Peer-driven Organization of Drug Users. Technical Report; 2001 Dec. Accessed from: http://pubs.cpha.ca/PDF/P1/20166.pdf.

47. Rossi C, Pacey K. Business group drops opposition to drug users' health Centre. Canadian HIV/AIDS policy. Law Rev. 2002;7(1):37.

48. Wood E, Kerr T, Spittal PM, Small W, Tyndall MW, O'shaughnessy MV, Schechter MT. An external evaluation of a peer-run "unsanctioned" syringe exchange program. J Urban Health. 2003;80(3):455-64

49. Kerr T, Wood E, Palepu A, Wilson D, Schechter MT, Tyndall MW. Responding to an explosive HIV epidemic driven by frequent cocaine injection: is there a role for safe injecting facilities? J Drug Issues. 2003;33(3):579-608.

50. Silversides A. No quick fix. C Med Assoc J. 2004;170(11):1703-4.

51. Alleyne B, Fiddler D, Liang G, Peeace W, Livingston A, Bear A, Finlay M, Livinstone C, Pierre, A., Chettiar, J., Breau, D., Hennan, M., Taylor, B., Power, C. , Campos, J., Levesque P, Palmer D, \& Wilson D. Creating vectors of disease prevention: empowering network of drug users. 2004. Accessed from: http://chodarr.org/sites/default/files/chodarr0137.pdf

52. Jürgens R. "Nothing about us without us"-greater meaningful involvement of people who use illicit drugs: a Public Health, ethical, and human rights imperative. 2005. Toronto: The Canadian HIV/AIDS Legal Network, International HIV/AIDS Alliance. Open Society Institute. Accessed from: http:/www.aidslaw.ca/site/wp-content/uploads/2013/04/Greater +Involvement+-+Bklt+-+Drug+Policy+-+ENG.pdf

53. Kerr T, Oleson M, Tyndall MW, Montaner J, Wood E. A description of a peerrun supervised injection site for injection drug users. J Urban Health. 2005; 82(2):267-75.

54. Shannon K, Ishida T, Morgan R, Bear A, Oleson M, Kerr T, Tyndall MW. Potential community and public health impacts of medically supervised safer smoking facilities for crack cocaine users. Harm Reduct J. 2006;3(1):1-8.

55. Osborn B, Small W. "Speaking truth to power": the role of drug users in influencing municipal drug policy. Int J Drug Policy. 2006;17(2):70-2.

56. De Sousa PA. Injection drug users' experiences with supervised injection sites. 2006; Doctoral dissertation: University of British Columbia.

57. Banga P. The core components of an early intervention treatment approach as perceived by substance misusing pregnant women. 2007. Doctoral dissertation: University of British Columbia.

58. Shannon K, Rusch M, Morgan R, Oleson M, Kerr T, Tyndall MW. HIV and HCV prevalence and gender-specific risk profiles of crack cocaine smokers and dual users of injection drugs. Subs Use Misuse. 2008:43(3-4):521-34.

59. Howard TR. Reading between the lines: a comparative analysis of exclusion versus inclusion of grey literature on conventional literature search results when developing a research question. 2008. Doctoral dissertation: Simon Fraser University.

60. Salmon A, Livingston A, Browne A, Pederson A, Dykstra L, Ham J, Parkes T, Chapman J, Charlie F, Dawson F, Hodgson F, Joe DJ, Leo D, Mayes J, Message S, \& Robinson J. "Me, I'm Living It": The Primary Health Care Experiences of Women who use Drugs in Vancouver's Downtown Eastside. 2009. Summary of Findings from the VANDU Women's Clinic Action Research for Empowerment Study. Accessed from: http://bccewh.bc.ca/wpcontent/uploads/2012/05/2009_Me-Im-Living-It.pdf

61. Boyd SC, MacPherson D, Osborn B. Raise shitl: social action saving lives. Fernwood Publication. 2009; 
62. Campbell L, Boyd N, Culbert LA. Thousand dreams: Vancouver's downtown eastside and the fight for its future: Greystone Books; 2009.

63. Wilson J. My voice, my voice, our community: a Vancouver DTES community action project. 2009. Doctoral dissertation: School of Communication-Simon Fraser University.

64. Rachlis B, Lloyd-Smith E, Small W, Tobin D, Stone D, Li K, Wood E, Kerr T. Harmful microinjecting practices among a cohort of injection drug users in Vancouver Canada. Subs Use Misuse. 2010;45(9):1351-66.

65. Vancouver Area Network of Drug Users. We're all Pedestrians": Final Report of the Downtown Eastside Pedestrian Safety Project. 2010. Accessed from: http://pedestriansafety.vandu.org/blog/\%22wp-content/uploads//2010/06/ WereAllPedestrians_EXECUTIVE-SUMMARY.pdf

66. Lloyd-Smith E, Rachlis BS, Tobin D, Stone D, Li K, Small W, Wood E, Kerr T. Assisted injection in outdoor venues: an observational study of risks and implications for service delivery and harm reduction programming. Harm Reduct J. 2010;7(1):1-5.

67. Kruk E, Banga PS. Engagement of substance-using pregnant women in addiction recovery. Canadian Journal of Community Mental Health. 201(30(1)):79-91.

68. Kendall PRW. Decreasing HIV infections among people who use drugs by injection in British Columbia. 2011. Accessed from: http://www.health.gov bc.ca/library/publications/year/2011/decreasing-HIV-in-IDU-population.pdf

69. Reid LA. Improving the quality of life for street level sex workers: a case study of their experiences with stigma in the Downtown Eastside. Master of Public Policy: Simon Fraser University; 2011.

70. Crabtree A, Latham N, Bird L, Lampkin H, Buxton J. Facilitators of and barriers to the inclusion of alcohol users in the drug user activist movement. UBC Med J. 2011 Apr;1:2(2).

71. Small W, Wood E, Tobin D, Rikley J, Lapushinsky D, Kerr T. The injection support team: a peer-driven program to address unsafe injecting in a Canadian setting. Subs Use Misuse. 2012;47(5):491-501.

72. McNeil R. The impact of environmental factors on risk, harm, and health care access among people who inject Drugs 2013. Doctoral dissertation, University of British Columbia.

73. Grant S, Tan T, Crabtree A, Mercer G, Horan R, Buxton JA. Barriers to Safer Injection Practices Faced by People Who Use Injection Drugs, in Vancouver and Abbotsford, BC. UBC Med J. 2013;4(2)

74. Callon C, Charles G, Alexander R, Small W, Kerr T. 'On the same level': facilitators' experiences running a drug user-led safer injecting education campaign. Harm Reduct J. 2013;10(1):4.

75. Ormond A. Jaywalking to jail: capitalism, mass incarceration and social control on the streets of Vancouver. Rad Crim. 2013;3:101-12.

76. McNeil R, Shannon K, Shaver L, Kerr T, Small W. Negotiating place and gendered violence in Canada's largest open drug scene. Int J Drug Policy. 2014;25(3):608-15.

77. McNeil R, Kerr T, Lampkin H, Small W. "We need somewhere to smoke crack": an ethnographic study of an unsanctioned safer smoking room in Vancouver, Canada. Int J Drug Policy. 2015;26(7):645-52.

78. Crabtree A. It's powerful to gather: a community-driven study of drug users' and illicit drinkers' priorities for harm reduction and health promotion in British Columbia, Canada. 2015. Doctoral dissertation: University of British Columbia.

79. Himsworth CG, Bai Y, Kosoy MY, Wood H, DiBernardo A, Lindsay R, Bidulka J, Tang P, Jardine C, Patrick D. An investigation of Bartonella spp., rickettsia typhi, and Seoul hantavirus in rats (Rattus spp.) from an inner-city neighborhood of Vancouver, Canada: is pathogen presence a reflection of global and local rat population structure? Vector-Borne Zoo Dis. 2015;15(1):21-6.

80. Westfall JA. Life Won't Wait: naloxone and drug overdose prevention in British Columbia. Master of Public Policy: Simon Fraser University; 2015.

81. Crabtree A, Latham N, Bird L, Buxton J. Results of a participatory needs assessment demonstrate an opportunity to involve people who use alcohol in drug user activism and harm reduction. Harm Reduct J. 2016;13(1):1-9.

82. Smith CB. "About nothing without us": a comparative analysis of autonomous organizing among people who use drugs and Psychiatrized groups in Canada. Intersectionalities: Glob J Soci Work Analysis, Res, Polity, and Prac. 2016;5(3):82-109.

83. Greer A, Luchenski S, Amlani A, Lacroix K, Burmeister C, \& Buxton J. Peer engagement in harm reduction strategies and services: Findings from a $B C$ case study, 2010-2014. 2016. British Columbia Centre for Disease Control. Accessed from: http://www.bccdc.ca/resource-gallery/Documents/ Summary\%20report\%20on\%20peer\%20engagement\%20case\%20study.pdf
84. Goodman A, Fleming K, Markwick N, Morrison T, Lagimodiere L, Kerr T. "They treated me like crap and I know it was because I was native": the healthcare experiences of aboriginal peoples living in Vancouver's inner city. Social Scie Med. 2017:178:87-94.

85. Thomson E, Lampkin H, Maynard R, Karamouzian M, Jozaghi E. The lessons learned from the fentanyl overdose crises in British Columbia, Canada. Addiction. 2017;112(11):2068-70.

86. Boyd S, Murray D, \& NAOMl Patients Association. Ethics, research, and advocacy: The experiences of the NAOMI patients association in Vancouver's Downtown Eastside. Crit Inquiries Soci Just Mental Health. 2017. 365-385.

87. Greer AM, Newman C, Burmeister C, Burgess H, Coll M, Choisil P, LeBlanc B, Lacroix K, Lampkin H, Amlani A, Pauly B, \& Buxton JA. Peer engagement principles and best practices: A guide for $\mathrm{BC}$ health authorities and other providers. 2017. British Columbia Centre for Disease Control. Accessed from: http://www.towardtheheart.com/assets/uploads/ 1516141269o4KkCMkq2ytmhxVyGjcQ9DSWtUol1d8FLnzYdlv.pdf

88. Bouchard M, Hashimi S, Tsai K, Lampkin H, Jozaghi E. Back to the core: a network approach to bolster harm reduction among persons who inject drugs. Int J Drug Policy. 2018;51:95-104.

89. Lee MJ, Byers KA, Donovan CM, Bidulka JJ, Stephen C, Patrick DM, Himsworth CG. Effects of culling on Leptospira interrogans carriage by rats. Emerg Infect Dis. 2018;24(2):356-60.

90. Rothenburger JL, Himsworth CG, Nemeth NM, Pearl DL, Jardine CM. Environmental Factors Associated with the Carriage of Bacterial Pathogens in Norway Rats. EcoHealth. 2018; in press

91. Jozaghi E, Maynard R, Dadakhah-Chimeh Z, Yake K, Blyth S. The synthetic opioid epidemic and the need for mental health support for first responders who intervene in overdose cases. C J Public Health. 2018; in press

\section{Ready to submit your research? Choose BMC and benefit from:}

- fast, convenient online submission

- thorough peer review by experienced researchers in your field

- rapid publication on acceptance

- support for research data, including large and complex data types

- gold Open Access which fosters wider collaboration and increased citations

- maximum visibility for your research: over $100 \mathrm{M}$ website views per year

At $B M C$, research is always in progress.

Learn more biomedcentral.com/submissions 